\title{
ERK Inhibitor LTT462
}

National Cancer Institute

\section{Source}

National Cancer Institute. ERK Inhibitor LTT462. NCI Thesaurus. Code C126687.

An orally available inhibitor of extracellular signal-regulated kinase (ERK), with potential antineoplastic activity. Upon oral administration, LTT462 binds to and inhibits ERK, thereby preventing the activation of ERK-mediated signal transduction pathways. This results in the inhibition of ERK-dependent tumor cell proliferation and survival. The mitogen-activated protein kinase (MAPK)/ERK pathway is upregulated in numerous tumor cell types and plays a key role in tumor cell proliferation, differentiation and survival. 